Published by LPMP Imperium

Journal homepage: https:/ / ejournal.imperiuminstitute.org/ index.php/JMSAB

\title{
Pengaruh Harga Dan Kualitas Produk Terhadap Kepuasan Konsumen T-Mart Express Indonesia
}

\section{Elizabeth Rahayu}

Manajemen, Sekolah Tinggi Ilmu Ekonomi Pengembangan Bisnis dan

Manajemen

\begin{abstract}
The purpose of this research is to understand the influence of price and product quality of T-Mart Express Indonesia's customer satisfaction. This research is a quantitative research by using the SPSS Statistic 22 with 112 respondent of the sample which is T-Mart Express Indonesia consumers in North Jakarta who have bought the product three times or more by using non-probability sampling method and purposive sampling techniques. The measurement used was a questionnaire that was distributed through Google Form to the respondent. The result of hypothesis analysis shows that price and product quality significantly affect customer satisfaction. Implications and suggestions are explained in the article.
\end{abstract}

\begin{abstract}
Abstrak
Tujuan dari penelitian ini adalah untuk memahami pengaruh harga dan kualitas produk terhadap kepuasan pelanggan T-Mart Express Indonesia. Penelitian ini adalah penelitian kuantitatif dengan menggunakan SPSS Statistic 22 dengan sampel sebanyak 112 responden yaitu konsumen T-Mart Express Indonesia di Jakarta Utara yang telah membeli produk tiga kali atau lebih dengan menggunakan metode non probability sampling dan teknik purposive sampling. Pengukuran yang digunakan adalah kuesioner yang dibagikan melalui Google Form kepada responden. Hasil analisis hipotesis menunjukkan bahwa harga dan kualitas produk berpengaruh signifikan terhadap kepuasan pelanggan. Implikasi dan saran dijelaskan pada artikel
\end{abstract}

*Email korespondensi: elisabethrahayu31071972@gmail.com

Pedoman Sitasi: Rahayu, E. (2020). Pengaruh Harga Dan Kualitas Produk Terhadap Kepuasan Konsumen T-Mart Express Indonesia. Jurnal Manajemen Strategi Dan Aplikasi Bisnis, 3(1), 1-10
JMSAB

1

Paper type

Research paper

Keywords: price, product quality, customer satisfaction, location
Received: 6 Dec 2019

Revised: 17 Jan 2020

Accepted: 20 Jan 2020

Online: 22 Jan 2020

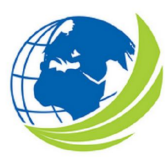

Jurnal Manajemen Strategi dan Aplikasi Bisnis, Vol 3, No.1, Januari 2020, pp. 1 - 10 eISSN 2655-237X

DOI: https:/ / doi.org/ 10.36407/jmsab.v3i1.114 


\section{PENDAHULUAN}

Perkembangan ekonomi dan persaingan usaha yang semakin ketat, kebutuhan akan orang semakin tinggi dan pemilih, termasuk makanan, kebutuhan sehari-hari, dan bahkan pakaian yang digunakan setiap hari. Konsumen semakin selektif dalam memilih produk yang dibelinya karena adanya berbagai pilihan yang tersedia di pasar, dan oleh karenanya upaya perusahaan untuk memberikan kepuasan kepada konsumen menjadi faktor kunci keberhasilan perusahaan untuk dapat bertahan di tengah persaingan sekarang ini.

Kepuasan pelanggan merupakan umpan balik pelanggan dalam bentuk evaluasi setelah membeli beberapa barang atau jasa dibandingkan dengan harapan pelanggan. Kepuasan pelanggan diukur dengan menggunakan harapan pelanggan dengan kinerja barang atau jasa yang dapat memenuhi kebutuhan dan keinginan pelanggan. Pelanggan yang puas berarti bahwa ada kesamaan antara kinerja barang dan jasa dengan harapan pelanggan, di mana itu akan mendorong mereka untuk membeli kembali produk. Pada saat yang sama, pelanggan yang kecewa akan membujuk pelanggan lain untuk tidak membeli kembali dan sebagai hasilnya, mereka akan pindah ke pesaing merek lain (Razak, Nirwanto, \& Triatmanto, 2016).

Model yang dikembangkan oleh Zeithaml (1988) memberikan penjelasan mengenai hubungan sebab akibat antara beberapa faktor dalam perilaku konsumen. Dalam model ini dijelaskan bahwa ada hubungan sebab akibat antara harga dan kualitas dengan nilai pelanggan. Di bidang pemasaran, persepsi kualitas dan harga pelanggan adalah faktor utama yang mempengaruhi kepuasan pelanggan (Clemes et al. 2008; Hanif, Hafeez, \& Riaz, 2010; Wu \& Lu, 2018). Karena persepsi kualitas lebih objektif, keputusan harus dibuat terutama berdasarkan harga (Dapkevičius \& Melnikas, 2011). Tantangan terbesar dari model penelitian ini adalah harga sering kali dijadikan sebagai pemoderasi hubungan kualitas dan kepuasan (Wang et al., 2018), dan hasil yang berbeda seperti Bei dan Chiao (2001) menunjukkan tidak berpengaruh pada kualitas produk dan harga terhadap kepuasan pelanggan.

Konsumen seringkali tidak dapat membuat perbandingan kualitas yang jelas di antara penjual, salah satu solusinya adalah mengikuti sinyal pasar yang berkualitas. Konsumen sering menggunakan harga sebagai sinyal kualitas produk / layanan ketika menghadapi ketidakpastian sebelum membuat keputusan (Wu dan Lu, 2018). Konsumen bersedia membayar harga lebih tinggi untuk penjual yang dapat mengurangi risiko yang dirasakan dan kepercayaan mereka. Bukti menunjukkan bahwa pemotongan harga yang besar kadang-kadang tidak membantu penjualan, tetapi justru menyebabkan persepsi konsumen potensial menganggap pemotongan harga sebagai sinyal kualitas yang buruk]. Dari perspektif ekonomi, harga menyampaikan permintaan dan pasokan. informasi kualitas terkait. Harga yang lebih tinggi mungkin mencerminkan permintaan yang lebih tinggi untuk produk / jasa yang berkualitas tinggi atau berbiaya tinggi. Hal ini menjadikan penentuan kualitas, harga yang lebih tinggi menghadirkan kualitas yang lebih tinggi, yang menghasilkan kepuasan yang lebih tinggi (Dapkevičius \& Melnikas, 2011). Dalam konteks ini jelas terlihat bahwa penetapan harga merupakan faktor krusial bagi perusahaan, terutama jika dihadapkan pada pelanggan yang memiliki persepsi harga mewakili kualitas.

Penelitian ini bertujuan (1) Untuk mengetahui dan menganalisis apakah harga mempengaruhi kepuasan konsumen T-Mart Express Indonesia; (2) Untuk mengetahui dan menganalisis apakah kualitas produk mempengaruhi kepuasan konsumen T-Mart Express Indonesia. Kontribusi dari penelitian ini adalah pengembangan dan validasi kerangka kerja yang telah secara efektif mengintegrasikan harga dan kualitas produk sebagai determinan kepuasan konsumen. Kerangka kerja yang digunakan dalam penelitian ini diambil dari Zeithaml (1988). Adanya perbedaan dalam penempatan variabel harga sebagai anteseden kepuasan perlu diteliti ulang dan dibandingkan efeknya dengan kualitas produk sehingga dapat memberikan informasi yang bermafaat bagi perusahaan pemasar dalam menetapkan strategi harganya. 


\section{KAJIAN PUSTAKA}

Kepuasan Konsumen

Menurut Kotler dan Keller yang dikutip oleh Bob Sabran (2012: 177) kepuasan konsumen adalah perasaan senang yang muncul setelah membandingkan antara kinerja atau hasil yang diharapkanya. Lalu menurut Fandy Tjiptono (2012: 146) kepuasan pelanggan adalah perasaan senang atau kecewa seseorang yang muncul setelah membandingkan antara persepsi terhadap kinerja (hasil) dari produk dengan harapan-harapanya. Selain itu itu, Daryanto dan Setyobudi (2014: 43) mengatakan kepuasan konsumen adalah setelah mengeluarkan emosional dari konsumen setelah konsumen menggunakan produk Dimana harapan dan kebutuhan pelanggan terpenuhi.

Berdasarkan beberapa di atas kepuasan konsumen adalah perasaan senang atau kecewa yang dirasakan konsumen atas pengalaman yang diperoleh dari produk yang ditawarkan oleh perusahaan dengan harapan. Seperti yang dilaporkan oleh konsumen Yulianto (2011: 34) yaitu perbedaan antara yang diharapkan konsumen (nilai harapan) dengan realisasi yang diberikan perusahaan dalam upaya memenuhi harapan konsumen (nilai presepsi) menanti: Sebuah. Nilai harapan =nilai persepsi maka pelanggan puas. Nilai harapan «nilai persepsi maka pelanggan sangat puas.

\section{Model Penelitian}

Model penelitian ini digambarkan dari variabel-variabel yang sudah dijabarkan di atas. Model penelitian yang digunakan dapat dilihat pada gambar di bawah ini:

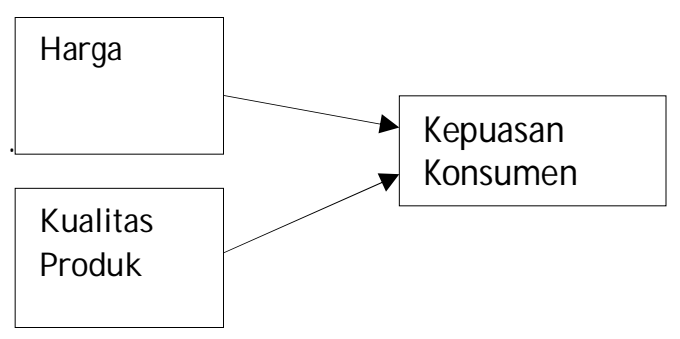

Gambar 1 Model Penelitian

Penelitian ini mengadaptasi model yang dikembangkan oleh Zeithaml (1988) mengemukakan bahwa ada hubungan sebab akibat antara harga dan kualitas dengan nilai pelanggan. Malik et al. (2012) yang menemukan bahwa harga dipengaruhi kepuasan pelanggan. Selanjutnya, penelitian Hanzaee dan Yazd (2010) menghasilkan bahwa harga berpengaruh pada nilai pelanggan. Razak, Nirwanto, \& Triatmanto (2016) dalam studinya juga menemukan bahwa harga merupakan faktor penting dalam mempengaruhi kepuasan konsumen. Keterkaitan antara kualitas produk dengan nilai kepuasan antara lain didukung oleh Jahanshahi et al. (2011) yang menjelaskan jika kualitas produk dipengaruhi kepuasan pelanggan. Penelitian lain yang memiliki poin serupa dengan penelitian ini adalah penelitian yang dilakukan oleh Munisih dan Soliha (2015) membuktikan bahwa kualitas produk dapat mempengaruhi nilai pelanggan. Beberapa temuan terbaru juga memperlihatkan pentingnya harga dalam meningkatkan kepuasan konsumen (Mohammed et al., 2017; Wowiling, \& Wahyudi, 2019; Saputra, Thalib, \& Hendratni, 2019; Razak, et al., 2016).

\section{Hubungan antara Harga terhadap Kepuasan Konsumen}

Menurut Oentoro (2012:150) harga memiliki peran yang sangat penting dalam mempengaruhi keputusan pembelian konsumen. Harga memiliki 2 peranan utama dalam proses pengambilan keputusan konsumen, yaitu peranan alokasi dan informasi. Peranan alokasi dari harga adalah fungsi harga dalam membantu konsumen untuk memutuskan cara memperoleh manfaat atau utilitas tertinggi yang diharapkan berdasarkan kekuatan membelinya. Pembeli cenderung membandingkan harga dari berbagai alternatif yang tersedia, kemudian memutuskan alokasi dana yang dikehendaki. 
Peranan informasi dari harga adalah untuk memberikan informasi kepada konsumen, misalnya kualitas. Persepsi yang sering berlaku dalam kalangan konsumen adalah bahwa harga yang mahal mencerminkan kualitas yang tinggi. Dari penjelasan mengenai harga diatas, dapat disimpulkan bahwa harga adalah suatu elemen dalam bauran pemasaran yang mempengaruhi pemasukan perusahaan dan mempengaruhi keputusan pembelian dari konsumen. Harga adalah sejumlah nilai tukar yang disamakan dengan manfaat barang yang diperoleh. Penetapan harga yang baik sangat diperlukan oleh perusahaan, karena harga berkaitan dengan bagaimana perusahaan menarik konsumen untuk mengkonsumsi produk mereka dan secara tidak langsung berpengaruh terhadap repurchasing atau pembelian kembali sebuah produk yang bersifat berkelanjutan. Suatu harga produk yang baik dapat dilihat berdasarkan kepuasan konsumen yang semakin meningkat. Semakin tinggi kepuasan konsumen maka harga yang diberikan kepada konsumen akan semakin baik. Berdasarkan penelitian terdahulu yang telah dilakukan oleh Malik et al. (2012) yang menemukan bahwa harga dipengaruhi kepuasan pelanggan. Selanjutnya, penelitian Hanzaee dan Yazd (2010) menghasilkan bahwa harga berpengaruh pada nilai pelanggan. Razak, Nirwanto, \& Triatmanto (2016) dalam studinya juga menemukan bahwa harga merupakan faktor penting dalam mempengaruhi kepuasan konsumen. Sehingga dapat dirumuskan hipotesis sebagai berikut:

$\mathrm{Ho}_{1} \quad$ : Harga tidak memiliki pengaruh terhadap kepuasan konsumen

Ha $\quad$ : Harga memiliki pengaruh terhadap kepuasan konsumen

\section{Hubungan antara Kualitas Produk terhadap Kepuasan Konsumen}

Kualitas produk menurut Kotler dan Amstrong (2012: 283) menyatakan bahwa kualitas produk adalah kemampuan sebuah produk dalam memperankan fungsinya, hal ini termasuk keseluruhan durabilitas, reliabilitas, ketepatan, kemudahan pengoperasian, reparasi produk, juga atribut produk lainnya. Menurut Tjiptono (2010: 14) kualitas produk adalah kualitas meliputi usaha memenuhi atau melebihi harapan pelanggan yang mencakup produk, jasa, manusia, proses dan lingkungan. Kualitas produk juga merupakan kondisi yang selalu berubah (misalnya apa yang dianggap kualitas saat ini berkualitas mungkin dianggap kurang berkualitas pada masa mendatang). Menurut Assauri dalam Arumsari (2012: 45), kualitas produk merupakan faktor-faktor yang terdapat dalam suatu barang atau hasil yang menyebabkan barang atau hasil tersebut sesuai dengan tujuan untuk apa barang atau hasil itu dimaksudkan. Dimensi kualitas produk menurut Tjiptono (2010: 25), mengemukakan bahwa kualitas produk memiliki dimensi antara lain:

1. Kinerja (Perfomances) merupakan karakteristik operasi dan produk inti (core product) yang dibeli. Misalnya kecepatan, kemudahan dan kenyamanan dalam penggunaan.

2. Ciri-ciri atau keistimewaan tambahan (Features) yaitu karakteristik sekunder atau pelengkap.

3. Kesesuaian dengan spesifikasi (Conformance to Spesification) yaitu sejauh mana karakteristik desain dan operasi memenuhi standar yang ditetapkan sebelumnya. Misalnya pengawasan kualitas dan desain, standar karakteristik operasional.

4. Keandalan (Realibility) yaitu kemungkinan kecil akan mengalami kerusakan atau gagal pakai.

5. Daya Tahan (Durability) berkaitan dengan berapa lama produk tersebut dapat terus digunakan. Dimensi ini mencakup umur teknis maupun umur ekonomis.

6. Estetika (Esthetica) yaitu daya tarik produk terhadap panca indra. Misal keindahan desain produk, keunikan model produk dan kombinasi.

7. Kualitas yang dipersepsikan (Perceived Quality) merupakan persepsi konsumen terhadap keseluruhan kualitas atau keunggulan suatu produk. Bianya karena kurangnya pengetahuan pembeli akan atribut atau ciri-ciri produk yang akan dibeli, maka pembeli akan mempresepsikan kualitasnya dari aspek harga, nama merek, iklan, reputasi perusahaan maupun negara pembuatnya.

8. Dimensi kemudahan perbaikan (Service Ability) meliputi kecepatan, kemudahan, penanganan keluhan yang memuaskan. Pelayanan yang diberikan tidak terbatas hanya sebelum penjualan, tetapi juga selama proses penjualan hingga purna jual yang mencakup layanan reparasi dan ketersediaan komponen yang dibutuhkan. 
Kualitas produk memiliki hubungan yang erat terhadap kepuasan konsumen. Semakin baik kualitas produk dari suatu perusahaan maka semakin terciptanya kepuasan konsumen. Tentunya kepuasan dari seorang konsumen dapat dilihat ketika mereka menggunakan produk tersebut dengan kualitas yang bagus. Berdasarkan penelitian terdahulu yang telah dilakukan oleh Munisih dan Soliha (2015); Mohammed et al. (2017); Wowiling, \& Wahyudi, (2019); Saputra, Thalib, \& Hendratni, (2019); Razak, et al. (2016) yang menunjukkan bahwa kualittas produk berpengaruh terhadap kepuasan konsumen. Sehingga dapat dirumuskan hipotesis sebagai berikut:

$\mathrm{Ho}_{2}$ : Kualitas Produk tidak memiliki pengaruh terhadap kepuasan konsumen

$\mathrm{Ha}_{2} \quad$ : Kualitas Produk memiliki pengaruh terhadap kepuasan konsumen

\section{METODE}

\section{Jenis Penelitian}

Penelitian ini merupakan penelitian yang bersifat kuantitatif, yaitu penelitian yang menggunakan angka-angka untuk ditarik kesimpulannya (Hendryadi et al., 2019). Pengumpulan data menggunakan instrumen penelitian, analisis data bersifat kuantitatif statistik, dengan tujuan untuk menguji hipotesis yang telah ditetapkan. Rumusan permasalahan kuantitatif asosiatif yaitu suatu rumusan masalah penelitian yang bersifat menanyakan hubungan antara dua variabel atau lebih. Dalam penelitian ini, variabel yang akan diuji adalah harga dan kualitas produk sebagai variabel independen dan kepuasan konsumen sebagai variabel dependen.

\section{Populasi dan Sampel}

Populasi dalam penelitian ini adalah warga Jakarta Timur dengan jumlah sampel yang digunakan sebesar 122 sampel yang di dapatkan dengan menggunakan teknik pengumpulan sampel yang digunakan dalam penelitian ini adalah dengan metode nonprobability sampling dengan metode purposive sampling.

\section{Operasional Variabel}

Operasionalisasi variabel penelitian merupakan penjelasan dari masing-masing variabel yang digunakan dalam penelitian terhadap indikator-indikator yang membentuknya. Harga adalah faktor positioning kunci dan harus diputuskan dalam hubungannya dengan pasar sasaran, bauran pilihan produk dan jasa, dan persaingan (Kotler dan Keller, 2011). Dengan dimensi daftar / harga pada indikator harga produk yang ditawarkan. Dengan dimensi rabat/diskon pada indikator tingkat diskon dan potongan harga yang diberikan penjual kepada konsumen. Dengan dimensi potongan harga khusus pada indikator potongan harga pada event tertentu. Dengan dimensi periode pembayaran, pada indikator kemudahan pembayaran yang di berikan penjual terhadap konsumennya.

Kualitas produk dan jasa didefinisikan sebagai keseluruhan gabungan karakteristik produk dan jasa yang dihasilkan dari pemasaran, rekayasa, produksi, dan pemeliharaan yang membuat produk dan jasa tersebut dapat digunakan memenuhi harapan pelanggan atau konsumen (Tony Wijaya 2011). Dengan dimensi kinerja pada indikator tingkat konsistensi dan kebaikan fungsi produk. Dengan dimensi tampilan pada indikator karakteristik produk dan cirri utama produk untuk membedakan dari pesaing. Dengan dimensi daya tahan pada indikator umur produk dan daya tahan produk. Dengan dimensi keindahan pada indikator penampilan produk.

Kepuasan pelanggan merupakan penilaian evaluatif purnabeli yang dihasilkan dari seleksi pembelian spesifik (Tjiptono 2014). Dengan dimensi kepuasan pelanggan keseluruhan pada indikator menanyakan kepada pelanggan seberapa puas mereka dengan produk. Dengan dimensi niat beli ulang pada indikator menanyakan apakah pelanggan akan berbelanja atau menggunakan jasa perusahaan lagi. Dengan dimensi konfirmasi harapan pada indikator kesesuaian/ ketidaksesuaian antara harapan pelanggan dengan kinerja aktual produk perusahaan. Dengan 
dimensi kesediaan untuk merekomendasi pada indikator merekomendasikan produk kepada teman atau keluarga.

\section{HASIL DAN PEMBAHASAN}

\section{Analisis Deskriptif}

Analisis deskriptif digunakan untuk memberikan gambaran mengenai data dan responden. Berdasarkan data yang diperoleh, dapat dijelaskan karakteristik responden sebagai berikut:

Tabel 1. Deskripsi Responden

\begin{tabular}{lcc}
\hline Usia & Jumlah & Persen \\
\hline$<20$ tahun & 38 & 33.93 \\
21 - 30 tahun & 43 & 38.39 \\
31 - 40 tahun & 21 & 18.75 \\
di atas 40 tahun & 10 & 8.93 \\
\hline Pendidikan & & \\
SMA Sederajat & 65 & 58.04 \\
Kuliah & 18 & 16.07 \\
S1 & 5 & 4.46 \\
Lain & 24 & 21.43 \\
\hline Jenis Kelamin & & \\
Wanita & 79 & 70.54 \\
Laki-Laki & 33 & 29.46 \\
\hline
\end{tabular}

Sumber: data diolah (2019)

Berdasarkan usia, mayoritas responden adalah berusia 21-30 tahun sebesar 38.39\%, kemudian usia kurang dari 20 tahun sebanyak 33.93\%, usia 31 - 40 tahun sebanyak $18.75 \%$, dan terakhir berusia di atas 40 tahun sebanyak 8.93\%. Dari sisi pendidikan, mayoritas responden berpendidikan SMA Sederajat (58.04\%), lain / tidak bersedia menjawab sebanyak $21.43 \%$. Responden yang masih berstatus kuliah sebanyak 16.07\%, dan yang sudah lulus Strata-1 sebanyak 4.46\%. Dari total 122 responden, sebanyak $70.54 \%$ adalah wanita, dan sisanya $29.46 \%$ adalah laki-laki.

\section{Analisis Regresi}

Uji determinasi digunakan untuk mengetahui seberapa besar persentase sumbangan pengaruh variabel independen terhadap variabel dependen. Pada kolom Adjusted R Square didapatkan nilai sebesar 0,699 yang berarti bahwa kepuasan konsumen sebesar 69,9\% dipengaruhi oleh harga dan kualitas produk, sisanya dipengaruhi oleh faktor dan variabel lainnya yang tidak dimasukkan dalam penelitian ini.

Tabel 1. Hasil Regresi

\begin{tabular}{lcc}
\hline \multicolumn{1}{c}{ Variabel } & Koefisien & Sig \\
\hline (Constant) & 1.817 & .835 \\
\hline Harga (X1) & .162 & .032 \\
\hline Kualitas Produk (X2) & .640 & .020 \\
\hline R Square & 0.699 & \\
\hline
\end{tabular}

Sumber: Olahan Peneliti, 2019

Berdasarkan tabel di atas maka persamaan regresi linear berganda dapat disimpulkan sebagai berikut: 
$\mathrm{Y}($ Kepuasan konsumen $)=1,817+0,162 \mathrm{X}_{1}($ Harga $)+0,640 \mathrm{X}_{2}($ Produk $)+\mathrm{e}$

Berdasarkan persamaan regresi linear berganda di atas maka hasilnya adalah:

Nilai Konstanta yang didapat adalah sebesar 1,817, artinya jika Harga $\left(\mathrm{X}_{1}\right)$ dan Kualitas Produk $\left(\mathrm{X}_{2}\right)$ ditiadakan ( bernilai 0) maka kepuasan konsumen (Y) bernilai 1,817. Sehingga tanpa adanya variabel independen yaitu harga dan kualitas produk, maka tetap terjadi kepuasan konsumen dalam membeli produk T-Mart Express Indonesia.

Koefisien regresi variabel harga $\left(\mathrm{X}_{1}\right)$ sebesar 0,162 , artinya jika variabel independen lainnya bernilai tetap dan harga $\left(\mathrm{X}_{1}\right)$ mengalami kenaikan sebesar 1, maka kepuasan konsumen $(\mathrm{Y})$ akan mengalami kenaikan sebesar 0,162. Sehingga T-Mart Express Indonesia perlu memperhatikan strategi harga mereka untuk memperbaiki dan mempertahankan kepuasan konsumen mereka. Koefisien regresi berganda Kualitas Produk $\left(\mathrm{X}_{2}\right)$ sebesar 0,640, artinya jika variabel independen lainnya bernilai tetap dan Kualitas Produk $\left(\mathrm{X}_{2}\right)$ mengalami kenaikan sebesar 1, maka kepuasan konsumen (Y) akan mengalami kenaikan sebesar 0,640. Sehingga T-Mart Express Indonesia perlu memperhatikan kualitas produk mereka untuk memperbaiki dan mempertahankan kepuasan konsumen mereka.

Penelitian ini berhasil membuktkan bahwa harga memiliki nilai strategis untuk memuaskan konsumen. Nilai koefisien sebesar 0.162 dengan sig $0.032(<0.05)$ mengindikasikan bahwa harga merupakan faktor relevan yang dapat mempengaruhi naik turunnya kepuasan konsumen. Hasil ini sejalan dengan studi sebelumnya yang menyatakan bahwa kesadaran harga di antara pelanggan bertindak sebagai bagian penting dalam kegiatan pengambilan keputusan pelanggan (Mohammed et al., 2017; Wowiling, \& Wahyudi, 2019; Saputra, Thalib, \& Hendratni, 2019). Dengan demikian, harga yang ditawarkan oleh bisnis apakah mahal atau murah, masuk akal atau tidak masuk akal bertindak sebagai patokan bagi pelanggan apakah akan melanjutkan pembelian atau tidak. Kesadaran pelanggan tentang harga yang ditawarkan oleh penyedia bisnis atau layanan memberikan keuntungan kepada pelanggan untuk membuat perbandingan dan untuk memutuskan apakah perusahaan atau penyedia layanan menawarkan harga yang wajar atau tidak.

Kualitas produk terbukti berpengaruh signifikan terhadap kepuasan konsumen dengan koefisien sebesar 0.640 dan sig 0.020. dapat dinyatakan bahwa kualitas produk merupakan faktor utama pembentuk kepuasan konsumen, dibandingkan harga. Penelitian ini mendukung temuan Malik et al. (2012); Hanzaee dan Yazd (2010); dan Razak et al. (2016) yang menemukan bahwa kualitas produk merupakan faktor penting yang dapat mempengaruhi kepuasan konsumen. Terkait dengan hasil ini, pihak perusahaan perlu memperhatikan dua faktor penting untuk memastikan kualitas produk yaitu yaitu kualitas produk yang diharapkan dan kualitas produk yang dirasakan. Secara rinci, jika kualitas produk yang dirasakan sesuai dengan harapan, maka pelanggan akan menganggap kualitas produk sebagai kualitas yang baik dan juga merasa puas. Sebaliknya, jika kualitas produk yang dipersepsikan tidak seperti yang diharapkan, maka kualitas produk seperti yang dirasakan pelanggan memenuhi syarat sebagai kualitas produk yang buruk. Dengan demikian, kualifikasi produk buruk dan baik tergantung pada kemampuan perusahaan untuk memenuhi harapan pelanggan.

\section{KESIMPULAN}

Berdasarkan hasil analisis dapat disimpulkan bahwa harga dan kualitas produk merupakan faktor penting yang dapat mempengaruhi kepuasan konsumen. Hasil uji statistik menunjukkan bahwa kedua faktor ini signifikan di level 5\% dengan kualitas produk sebagai faktor utama yang memiliki nilai koefisien tertinggi. Implikasi temuan ini adalah penting bagi perusahaan untuk memperhatikan kualitas produk yang tidak hanya tidak ditinjau oleh sudut pandang perusahaan, namun juga dilihat dari perspektif pelanggan. Terkait dengan itu, perusahasan perlu meningkatkan kualitas produk yang 
ditawarkan, sekaligus dengan cara menyesuaikan antara kualitas produk dengan harga yang ditawarkan. Jika kualitas produk yang dirasakan sesuai dengan harapan, maka pelanggan akan menganggap kualitas produk sebagai kualitas yang baik dan juga merasa puas. Sebaliknya, jika kualitas produk yang dipersepsikan tidak seperti yang diharapkan, maka kualitas produk yang dirasakan pelanggan memenuhi syarat sebagai kualitas produk yang buruk. Dengan demikian, kualifikasi produk buruk dan baik tergantung pada kemampuan perusahaan untuk memenuhi harapan pelanggan.

\section{Keterbatasan}

Penelitian ini memiliki keterbatasan dari sisi penggunaan variabel dan ukuran sampel yang digunakan. Penelitian mendatang perlu mempertimbangkan faktor lain seperti brand image sebagai enteseden kepuasan konsumen, serta menempatkan jenis kelamin, pendidikan, dan penghasilan sebagai pemoderasi hubungan harga dengan kepuasan. Selain itu, ukuran sampel perlu di perbesar untuk memberikan hasil yang lebih dapat digeneralisasi.

\section{REFERENSI}

Bei, L. T., \& Chiao, Y. C. (2001). An integrated model for the effects of perceived product, perceived service quality, and perceived price fairness on consumer satisfaction and loyalty. Journal of consumer satisfaction, dissatisfaction and complaining behavior, 14, 125.

Clemes, M. D., Gan, C., Kao, T. H., \& Choong, M. (2008). An empirical analysis of customer satisfaction in international air travel. Innovative Marketing, 4(2), 50-62.

Dapkevičius, A., \& Melnikas, B. (2011). Influence of price and quality to customer satisfaction: neuromarketing approach. Science-Future of Lithuania/ Mokslas-Lietuvos Ateitis, 1(3), 17-20.

Della Bitta, A. J., Monroe, K. B., \& McGinnis, J. M. (1981). Consumer perceptions of comparative price advertisements. Journal of Marketing Research, 18(4), 416-427.

Ghozali, I. (2013). Aplikasi Analisis Multivariate Dengan Program SPSS Edisi 7. Semarang: Badan Penerbit Universitas Diponegoro.

Hanif, M., Hafeez, S., \& Riaz, A. (2010). Factors affecting customer satisfaction. International research journal of finance and economics, 60(1), 44-52.

Hendryadi, Tricahyadinata, I., \& Zannati, R (2019). Metode Penelitian: Pedoman Penelitian Bisnis dan Akademik. Jakarta: Lembaga Pengembangan Manajemen dan Publikasi Imperium

Jahanshahi, A. A., Gashti, M. A. H., Mirdamadi, S. A., Nawaser, K., \& Khaksar, S. M. S. (2011). Study the effects of customer service and product quality on customer satisfaction and loyalty. International Journal of Humanities and Social Science, 1(7), 253-260.

Kotler, P., \& Keller, K. L. (2009). Manajemen Pemasaran Jilid 1 Edisi ke 13. Jakarta: Erlangga.

Kotler, P and Amstrong, G. (2012). Principle of Marketing.14th Edition. New Jersey. Published by Prentice Hall

Malik, M. E., Ghafoor, M. M., \& Hafiz, K. I. (2012). Impact of Brand Image, Service Quality and price on customer satisfaction in Pakistan Telecommunication sector. International journal of business and social science, 3(23).

Mohammed, N. H., Abdullah, S., Salleh, S. M., Rashid, K. M., Hamzah, S. F. M., \& Sudin, N. (2017). Relationship among Service and Product Quality, and Price in Establishing Customer Satisfaction. Journal of Applied Environmental and Biological Sciences, 7(5S), 45-50.

Priyatno, D. (2008). Mandiri Belajar SPSS Untuk Analisis Data dan Uji Statistik. Yogyakarta: MediaKom.

Purnamasari, Y. (2015). Pengaruh Kualitas Produk Dan Harga Terhadap Kepuasan Konsumen Produk M2 Fashion Online Di Singaraja Tahun 2015. Jurnal Jurusan Pendidikan Ekonomi .

Razak, I., Nirwanto, N., \& Triatmanto, B. (2016). The impact of product quality and price on customer satisfaction with the mediator of customer value. Journal of Marketing and Consumer Research, 30(1), 59-68. 
Saputra, N., Thalib, S., \& Hendratni, T. (2019). PENGARUH KUALITAS PRODUK DAN KUALITAS PELAYANAN TERHADAP KEPUASAN KONSUMEN PADA ONLINE STORE GUZZLE DI MEDIA SOSIAL. Jurnal Riset Manajemen Dan Bisnis (JRMB) Fakultas Ekonomi UNIAT, 4(S1), 709 - 718

Setyo, P. E. (2017). Pengaruh Kualitas Produk Dan Harga Terhadap Kepuasan Konsumen "Best Autoworks". PERFORMA: Jurnal Manajemen dan Start-Up Bisnis , 755-764.

Sugiyono. (2018). Metode Penelitian Kuantitatif, Kualitatif, dan R\&D. Bandung: Alfabeta.

Tjiptono, F. (2014). Pemasaran Jasa Prinsip, Penerapan, dan Penelitian. Yogyakarta: Andi.

Wang, J. N., Du, J., Chiu, Y. L., \& Li, J. (2018). Dynamic effects of customer experience levels on durable product satisfaction: Price and popularity moderation. Electronic Commerce Research and Applications, 28, 16-29.

Wijaya, T. (2011). Manajemen Kualitas Jasa. Jakarta: Indeks.

Wu, H., \& Lu, N. (2018). Service provision, pricing, and patient satisfaction in online health communities. International journal of medical informatics, 110, 77-89.

Wowiling, Y., \& Wahyudi, T. (2019). FAKTOR DETERMINAN KEPUASAN DAN LOYALITAS KONSUMEN: PERAN PERSEPSI HARGA SEBAGAI PEMODERASI. Jurnal Riset Manajemen Dan Bisnis (JRMB) Fakultas Ekonomi UNIAT, 4(1), 153 - `164

Zeithaml, V. A. (1988). Consumer perceptions of price, quality, and value: a means-end model and synthesis of evidence. Journal of marketing, 52(3), 2-22.

\section{PROFIL PENULIS}

Elisabeth Sri Riwayati Rahayu adalah dosen di program studi manajemen Sekolah Tinggi Ilmu Ekonomi Pengembangan Bisnis dan Manajemen (STIE PBM) mata kuliah yang diampu adalah Bahasa Inggris. 
Jurnal Manajemen Strategi dan Aplikasi Bisnis, 2(2), 1-10

Elizabeth Rahayu. Harga, Kualitas dan Kepuasan Konsumen

This page intention to blank... 